\title{
Information Flows Between Eurodollar Spot and Futures Markets
}

\author{
Yin-Wong Cheung \\ University of California-Santa Cruz, U.S.A. \\ Hung-Gay Fung \\ University of Missouri-St. Louis, U.S.A.
}

\begin{abstract}
The pattern of information flows between Eurodollar spot and futures markets is examined using a robust two-step procedure. This procedure allows for conditional mean and variance dynamics as well as conditional heteroskedasticity. We find spot rates affect futures data and vice versa. In addition, there is evidence of volatility spillover between the two markets. Our results also indicate that information conveyed by data on futures tends to have a more persistent impact on both the mean and volatility of cash market price movements than the other way around (JEL C12, G15, G10).
\end{abstract}

Keywords: Granger causality, cointegration, Eurodollar spot and futures interest rates, information flow.

\section{Introduction}

Since its inception in the late 1950s, the Eurodollar market has become an important component of the international capital market. Its estimated market size grew from less than $\$ 1$ billion in 1958 to about $\$ 4$ trillion in the early 1990s, and multinational firms and financial institutions rely increasingly on the Eurodollar market for funds and interest rate information (Melton and Pukula [1984]).

The rapid growth of the Eurodollar market is accompanied by that of Eurodollar futures. Eurodollar futures contracts, introduced in December 1981 by the International Monetary Market in Chicago, are

\footnotetext{
${ }^{*}$ We would like to thank Geoffrey Booth (Editor), Nancy Horowitz, Wai Lee, Peter Theodossiou (Managing Editor), and two anonymous reviewers for their valuable comments.

(Multinational Finance Journal, 1997, vol. 1, no. 4, pp. 255-271)

(C) by Multinational Finance Society, a nonprofit corporation. All rights reserved.
} 
the most actively traded short-term interest contract.

Futures markets play a major economic role by facilitating the price discovery function; that is, the ability to discover present and future equilibrium prices (Krehbiel and Adkins [1994], Hein and MacDonald [1993], Fama and French [1987], and Garbade and Silber [1983]). Prices assimilate information faster in the futures market than in the spot market because of the futures market's lower transaction costs and higher liquidity. This suggests futures prices may contain useful information on spot prices.

Existing empirical studies on information flows between spot and futures markets typically examine causality in the mean relationship between data on spot and futures prices. However, recently there is a growing literature on the relationship of conditional variances across financial markets and this relationship's implications concerning information transmission mechanisms, e.g., Susmel and Engle (1994), Najand, Rahman, and Yung (1992), Baillie and Bollerslev (1991), and Hamao, Masulis, and Ng (1990). In addition, Ross (1989) uses a no-arbitrage model to show information transmission is primarily related to the volatility of price changes. Finally, Engle, Ito, and Lin (1990) provide an alternative interpretation that relates information processing time to variance movements. This development suggests price volatility has significant implications concerning information linkages between markets.

This article attempts to characterize the pattern of information flows between the Eurodollar spot and futures markets by using price and volatility spillovers. A two-step procedure proposed by Cheung and $\mathrm{Ng}$ (1996) is employed to determine mean and variance causal relationships. An advantage of the Cheung and $\mathrm{Ng}$ method is that it allows for conditional mean and variance dynamics in the testing procedure. Another attractive feature is that its asymptotic behavior does not depend on the normality assumption, which is known to be violated by data on Eurodollar rates.

Specifically, the article examines the mean and volatility causation relationships between Eurodollar spot and futures markets. Such information can be exploited to better model conditional mean and variance behavior. For practitioners, a superior model of interest rate movements may lead to more accurate assessment of interest costs of funding and, thus, improved interest rate risk management. 
The article is organized as follows: Section II presents a selected literature review. Section III discusses the data and presents some preliminary results. Section IV presents the causality test methodology and reports the estimated causality patterns of Eurodollar spot and futures deposit rates. Concluding remarks are offered in section V.

\section{Selected Literature Review}

The pricing relationship between cash and futures markets has been extensively studied. For example, Khoury and Yourougou (1991), MacDonald and Hein (1989), and Fama and French (1987) examine the price discovery function in various futures markets. Their results generally show that the futures market provides useful information about spot market price movements.

Some recent studies focus on the price interaction between cash and futures markets. Chan (1992) examines the intra day lead-lag relation between returns of the major market cash index, the major market index futures, and the S\&P 500 futures. Stoll and Whaley (1990) analyze the contemporaneous correlation between stock cash and futures indexes. Cointegration models are also used to investigate the empirical long-run relationship between spot and futures prices. For example, Tse and Booth (1997) use a cointegration model to investigate information transmission between New York heating oil futures and London gas oil futures prices. Fung and Leung (1993) document that spot and futures prices are cointegrated in the Eurodollar market, while Bessler and Covey (1991) find evidence of cointegration using price data on U.S. cattle.

Most empirical studies use return data to infer the information linkage between cash and futures markets. However, as demonstrated by Ross (1989), return volatility also provides useful information on information flow. Thus, data on return volatility in spot and futures markets can provide information in addition to that available in the return data alone. Chan, Chan, and Karolyi (1991) examine the intraday volatility relation between the stock cash index and its futures. Cheung and Ng (1996) develop a causality test based on crosscorrelation functions and apply the test to five-minute S\&P cash and futures data. They show that information on causality in mean and variance helps devise a better model to describe the temporal dynamics and the interaction of the S\&P cash and futures data. 


\section{Preliminary Data Analysis}

Daily data on the three-month Eurodollar spot rate and the nearby Eurodollar futures rate from January 1983 to July 1997 are used in this article. Spot rates are obtained from the Eurodollar market in London. Futures data are rates on a Eurodollar futures contract that calls for the delivery of a \$1 million, three-month Eurodollar deposit. Eurodollar futures trade on the International Money Market (IMM) of the Chicago Mercantile Exchange (CME). The data set is obtained from Datastream and contains 2,634 observations.

\section{A. Descriptive Statistics}

Table 1 presents some descriptive statistics for the spot and futures data. All the skewness and kurtosis coefficients are significantly different from those of a normal distribution. Both spot and futures interest rates are extremely persistent, as indicated by the autocorrelation estimates $\rho(1)$ to $\rho(5)$. The Eurodollar spot rates, in both levels and first differences, tend to have a lower mean and variance than the futures rates. As indicated by the unit root tests reported below, the two interest rate series are better modeled as an integrated series. On the other hand, the differenced series exhibit weak correlation persistence.

The existence of a unit root is examined using the augmented Dickey-Fuller (ADF) test, which allows for both a constant and a time trend, and the test proposed by Kwiatkowski, Phillips, Schmidt, and Shin (1992) (KPSS). The lag length parameter of the ADF test is determined using the Akaike information criterion (AIC) and the Schwarz Bayesian criterion (SBC). As shown in table 1, the results based on both ADF and KPSS tests indicate that the levels of Eurodollar spot and futures rates are non-stationary, while their first differences are stationary.

\section{B. Results of the AR-GARCH model}

Before discussing the results concerning the interaction between Eurodollar spot and futures interest rates, we present some formal evidence on short-term dependence and conditional heteroskedasticity in the data. An AR-GARCH process is used to model interest rate dynamics because of its recorded success (e.g. Engle, Lilien and Robins [1987] and Chan, Karolyi, Longstaff, and Saunders [1992]). 
TABLE 1. Summary Statistics for Eurodollar Spot and Futures Interest Rates

\begin{tabular}{lcccrr}
\hline & \multicolumn{2}{c}{ Levels } & & \multicolumn{2}{c}{ First Differences } \\
\cline { 2 - 4 } & Spot & Futures & Spot & Futures \\
\hline Mean & 6.875 & 7.032 & -.001 & -.001 \\
Variance & 4.878 & 5.086 & .006 & .009 \\
Skewness & .114 & .232 & -.527 & 1.588 \\
Kurtosis & -.709 & -.534 & 11.584 & 33.569 \\
$\rho(1)$ & .999 & .999 & -.036 & .012 \\
$\rho(2)$ & .998 & .998 & -.034 & .011 \\
$\rho(3)$ & .998 & .997 & .021 & .007 \\
$\rho(4)$ & .997 & .996 & .051 & .008 \\
$\rho(5)$ & .996 & .995 & -.003 & -.014 \\
ADF-AIC & $-1.500^{\mathrm{b}}$ & $-1.804^{\mathrm{a}}$ & $-29.58^{*}$ & $-60.82^{*}$ \\
ADF-SBC & -1.461 & -1.804 & $-63.79 *$ & $-60.82^{*}$ \\
KPSS-4 & $2.1574^{*}$ & $2.1593^{*}$ & .1088 & .0714 \\
KPSS-8 & $1.0844^{*}$ & $1.0879^{*}$ & .1022 & .0721 \\
KPSS-12 & $.7269^{*}$ & $.7309^{*}$ & .0966 & .0696 \\
\hline
\end{tabular}

Note: The skewness statistic is $S_{k}[(N-1)(N-2) / 6 N]^{5}$, where $S_{k}=N^{2} m_{3} /[(N-1)(N-2)]$ $s^{3} . N$ is the number of observations, $m_{i}$ is the $i^{\text {th }}$ moment, and $s$ is the standard deviation. The kurtosis test statistic is $K_{u}\left\{[(N-1)(N-2)(N-3) /[24 N(N+1)]\}^{.5}\right.$, where $K_{u}=N^{2}\left[(N+1) m_{4}-3\right.$ $\left.(N-1) m_{2}{ }^{2}\right] /\left[(N-1)(N-2)(N-3) s^{4}\right] . \quad \rho(\mathrm{k})$ is the $k$-lag autocorrelation. ADF-AIC and ADF$\mathrm{SBC}$ are the augmented Dickey-Fuller test models identified using the Akaike Information Criterion and the Schwarz Bayesian Criterion. Unless otherwise noted, one lag was used in

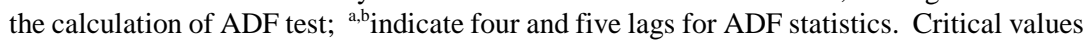
for the ADF statistics are from Cheung and Lai (1995). *Indicates significance at the 5\% level. KPSS- $x$ is the KPSS statistic according to the $\mathrm{x}$-rule.

For a time series, $\{Z(t)\}, t=1, \ldots, T$, an AR-GARCH process is given by

$$
\begin{gathered}
Z_{t}=a_{0}+\sum_{i=1}^{p 1} a_{i} Z_{t-i}+\varepsilon_{t}, \\
h_{t}=\beta_{0}+\sum_{i=1}^{p 2} \beta_{i} \varepsilon_{t-i}^{2}+\sum_{i=1}^{p 3} \gamma_{i} h_{t-i},
\end{gathered}
$$

where $\varepsilon_{t \mid t-1} \sim N\left(0, h_{t}\right)$. Equation 1 describes the conditional mean dynamics, $\varepsilon_{t}$ is the heteroskedastic error term with its conditional variance $h_{t}$, and $p 1$ to $p 3$ are lag parameters. ${ }^{1}$

1. An EGARCH model can also be used to examine the information transmission issue. 
TABLE 2. AR-GARCH Models for Eurodollar Spot and Futures Interest Rates

\begin{tabular}{lcccc}
\hline & \multicolumn{2}{c}{ Spot } & \multicolumn{2}{c}{ Futures } \\
\hline$a_{1}$ & -.0666 & $(-3.66)$ & .0278 & $(1.92)$ \\
$a_{2}$ & -.0354 & $(-2.07)$ & & \\
$\beta_{0}$ & .0096 & $(10.92)$ & .0012 & $(16.89)$ \\
$\beta_{1}$ & .1016 & $(19.80)$ & .0136 & $(30.17)$ \\
$\gamma_{1}$ & .3197 & $(6.07)$ & .9852 & $(21.18)$ \\
$\gamma_{2}$ & .5664 & $(11.30)$ & & \\
Log-likelihood & 4771.51 & 3999.36 \\
$Q(5)$ & \multicolumn{2}{c}{10.4} & \multicolumn{2}{c}{1.63} \\
$Q(10)$ & \multicolumn{2}{c}{13.2} & \multicolumn{2}{c}{8.92} \\
$Q^{2}(5)$ & \multicolumn{2}{c}{5.11} & 3.03 \\
$Q^{2}(10)$ & \multicolumn{2}{c}{8.31} & 4.13 \\
\hline
\end{tabular}

Note: The estimates are for the AR-GARCH model given by equations 1 and 2 . The intercept for the conditional mean equation, $a_{0}$, being insignificant, is excluded. $\beta_{0}$ is multiplied by a factor of $100 . Q(k)$ and $Q^{2}(k)$ are the Ljung-Box statistics with $k$ lags for the standardized residuals and their squares. $t$-values for the estimates are given in parentheses.

Results of fitting AR-GARCH models to changes in the Eurodollar spot and futures interest rate data are reported in table 2. Information criteria and diagnostic statistics are used to select final models from various possible AR-GARCH specifications. The maximum likelihood estimates confirm that changes in spot and futures rates exhibit significant conditional heteroskedasticity. The fitted models indicate that the spot interest rate data have a more complex conditional mean and conditional variance dynamic. The $Q(q)$ and $Q^{2}(q)$ statistics, which are calculated from the first $q$ autocorrelation coefficients of the standardized residuals and their squares, suggest that the selected specifications explain the data fairly well.

Given the evidence of GARCH effects, study of the interaction between the Eurodollar spot and futures interest rates should properly control for conditional heteroskedasticity. For instance, the presence of conditional heteroskedasticity may render inefficient the standard test for causality (Engle [1982]). In addition, the GARCH specification provides a convenient framework to investigate volatility spillovers between Eurodollar spot and futures rates. The causality test results allowing for GARCH effects are discussed in section IV.

See Theodossiou (1994) and Koutmos and Theodossiou (1994) for the EGARCH model. Our model has a conditional normal distribution assumption. However, the test results of the causal pattern reported in section IV do not depend on this normality assumption. 
TABLE 3. Cointegration Test Results

\begin{tabular}{llcc}
\hline & & EI-STAT & TR-STAT \\
\hline Null Hypothesis: & $r=0$ & $74.0^{*}$ & $75.66^{*}$ \\
& $r=1$ & 1.65 & 1.66 \\
Cointegrating vector $=[1,-.9848]$ & & \\
$Q$-statistics & Spot & Futures \\
$Q(5)$ & 4.92 & .85 \\
$Q(10)$ & 15.04 & 12.67 \\
\hline
\end{tabular}

Note: $r$ is the number of cointegration vector. EI-STAT is the maximum eigenvalue statistic. TR-STAT is the trace statistic. $Q$-statistics give the Ljung-Box statistics calculated from the residuals of the estimated spot and futures interest rate equations. $Q(k)$ is computed from the first $k$ autocorrelations of the residuals. The maximum lag used in conducting the test, as selected by both the AIC and SBC, is three. Critical values are taken from Cheung and Lai (1993). *Statistics significant at the $1 \%$ level.

\section{Cointegration Analysis}

For a system of non-stationary series, the presence of cointegration among them has significant implications for modeling the dynamics of individual series. For instance, in the presence of cointegration, an error correction term should be included when one describes the time-series behavior of the first differences of the series. As the Eurodollar spot and futures data used in this article may be cointegrated (Fung and Leung [1993]), we have to determine whether an error correction term should be incorporated in the subsequent causality analysis. The Johansen (1991) procedure is used to test if cointegration exists between the spot and futures series. ${ }^{2}$

Table 3 reports the Johansen cointegration test results. The model used to conduct the cointegration test is quite adequate, as indicated by the $Q$-statistics. Both the maximum eigenvalue and trace statistics agree that there is (only) one cointegration relationship between the spot and futures series. The normalized cointegration vector $[1,-.9848]$ is not significantly different from $[1,-1]$. Thus, the error correction term based on the difference between the spot and futures interest rates will be incorporated in the subsequent causality analysis. ${ }^{3}$

2. The Johansen procedure is more efficient than the two-step Engle and Granger approach, e.g., Phillips (1991).

3. We thank Geoffrey Booth for suggesting this specification of the error correction term. Results using the error correction term constructed from the estimated cointegration vector are qualitatively the same as those reported in the following sections. 


\section{The Standard Granger Causality Test}

We first apply the conventional Granger causality test to study the price interaction between the spot and futures markets. The Granger causality is determined using the equations

$$
\Delta S_{t}=a_{0}+\sum_{i=1}^{p 1} a_{i} \Delta S_{t-i}+d E_{t-i}+\varepsilon_{s, t}
$$

and

$$
\Delta S_{t}=a_{0}+\sum_{i=1}^{p 1} a_{i} \Delta S_{t-i}+\sum_{i=1}^{p 2} b_{i} \Delta F_{t-i}+d \mathrm{E}_{t-1}+\varepsilon_{s, t},
$$

where $S_{t}$ is the Eurodollar spot rate, $F_{t}$ is the Eurodollar futures rate, $E_{t-1}$ is the error correction term, $\varepsilon_{s, t}$ is an error term, and $\Delta$ is the difference operator.

The ability of past values of $\Delta S_{t}$ to explain the current values of $\Delta S_{t}$ is captured by equation 3 . The error correction term, specified as the difference between spot and futures interest rates, captures the possible effects of deviations from the estimated long-run relationship. Information criteria are used to determine the lag order parameters $p 1$ and $p 2 . \Delta F_{t}$ is the change in the Eurodollar futures interest rate. The null hypothesis that futures data do not Granger cause spot data is rejected when $b_{\mathrm{i}}$ 's, the coefficients of the lagged futures data, are not jointly insignificant. On the other hand, the hypothesis that spot data do not Granger cause futures data is tested using the following regressions:

$$
\Delta F_{t}=a_{0}+\sum_{i=1}^{p 1} a_{i} \Delta F_{t-i}+d E_{t-1}+\varepsilon_{f, t},
$$

and

$$
\Delta F_{t}=a_{0}+\sum_{i=1}^{p 1} a_{i} \Delta F_{t-i}+\sum_{i=0}^{p 2} b_{i} \Delta S_{t-i}+d E_{t-1}+\varepsilon_{f, t} .
$$

Results of testing the hypothesis that futures data do not Granger cause spot data are reported under the column labeled "Spot" in table 4 . The lag-order parameters $p 1$ and $p 2$ are determined sequentially using information criteria. The inclusion of lagged futures data improves the adjusted R-square by about a factor of 4 . The F-statistic of 254.75 suggests that coefficients $b_{i}$ 's are jointly significant; that is, Eurodollar futures rates cause spot Eurodollar rates. 
TABLE 4. Results of the Standard Granger Causality Test

\begin{tabular}{lrrrrrrrrr}
\hline & \multicolumn{3}{c}{ Spot } & \multicolumn{7}{c}{ Futures } \\
\hline$a_{0}$ & -.0093 & $(-6.46)$ & -.0053 & $(-3.87)$ & .0017 & $(.96)$ & .0017 & $(.96)$ \\
$a_{1}$ & -.0414 & $(-2.59)$ & -.1982 & $(-11.51)$ & .0220 & $(1.35)$ & .0052 & $(.29)$ \\
$a_{2}$ & -.0394 & $(-2.47)$ & -.0965 & $(-5.99)$ & & & & \\
$a_{3}$ & .0068 & $(.42)$ & -.0096 & $(-.64)$ & & & & \\
$a_{4}$ & .0381 & $(2.38)$ & .0391 & $(2.60)$ & & & & \\
$a_{5}$ & -.0074 & $(-.46)$ & .0032 & $(.22)$ & & & & \\
$a_{6}$ & -.0409 & $(-2.57)$ & -.0378 & $(-2.52)$ & & & & \\
$b_{1}$ & & & .3032 & $(22.34)$ & & & .0594 & $(2.86)$ \\
$b_{2}$ & & & .0978 & $(6.85)$ & & & .0335 & $(1.70)$ \\
$d$ & -.0540 & $(-11.84)$ & -.0292 & $(-6.76)$ & .0169 & $(2.96)$ & .0163 & $(2.85)$ \\
Adj. $R^{2}$ & .0402 & & .1538 & & .0019 & & .0042 \\
F-Statistic & & 254.75 & & & & 5.28 & \\
\hline
\end{tabular}

Note: This table presents estimates for Granger-causality models given by equations 1 , 2,3 , and 4 . The lag parameters, $p 1$ and $p 2$, of these models are determined using the AIC criterion. The $\mathrm{F}-$ statistics test the null hypothesis that the $b_{i}$ 's are jointly insignificant.

The results of testing the hypothesis that spot data do not Granger cause futures data are summarized under the column labeled "futures" in table 4. The F-statistic is 5.28. The spot Eurodollar rates have incremental explanatory power for the futures rates. That is, there is feedback between the spot and futures markets. However, changes in adjusted $R^{2}$ suggest the futures market has a larger impact on the spot market than the latter one on the former.

\section{Causal Relationships}

In this section we report causality test results based on the Cheung and $\mathrm{Ng}$ (1996) procedure, which tests for causal relationships in the mean and in the variance. The test procedure is based on the standardized residuals and their squares estimated from individual AR-GARCH models. Using notation in equations 1 and 2, the standardized residual is defined by $\varepsilon_{t} / \sqrt{h_{t}}$. Causality in mean is tested using cross correlation coefficients between standardized residuals, while causality in variance is investigated using the squares of standardized residuals. ${ }^{4}$

4. For an alternative approach to conducting a causality test in a multivariate GARCH framework, see Theodossiou and Lee (1993). 
TABLE 5. Cross-Correlation Analysis for the Levels and Squares of the Standardized Residuals

\begin{tabular}{rrrrrr}
\hline Lag $k$ & Levels & Squares & Lag $k$ & Levels & Squares \\
\hline-10 & -.9280 & .9557 & 1 & $2.7537 *$ & -.6996 \\
-9 & .9910 & 1.1794 & 2 & 1.8551 & -.2661 \\
-8 & -.4782 & -.7097 & 3 & .8774 & $2.5375^{*}$ \\
-7 & 1.4489 & -1.3202 & 4 & -.6095 & -.3607 \\
-6 & .8069 & .5373 & 5 & 1.8631 & 1.0162 \\
-5 & $2.5736^{*}$ & .9034 & 6 & .3628 & .8174 \\
-4 & .6024 & -.2340 & 7 & .2965 & -1.0101 \\
-3 & $2.0112^{*}$ & -.6135 & 8 & -1.3146 & .3925 \\
-2 & $4.9757^{*}$ & .3167 & 9 & .8683 & .6912 \\
-1 & $19.9032 *$ & $4.0912^{*}$ & 10 & .4562 & .6928 \\
0 & $16.4739 *$ & $6.4721^{*}$ & & & \\
& & & & &
\end{tabular}

Note: Cross-correlations are calculated from the standardized residuals and their squares obtained from the models in table 2. $k$ is the number of days the spot data lag the futures data. A lead is given by a negative lag parameter. *Indicates significance at the $5 \%$ level.

It can be shown that, under the no-causality hypothesis, the cross correlations at different lags are independently and normally distributed in large samples. That is, there is no evidence of causality in mean (variance) when all the cross-correlation coefficients calculated from (squares of) standardized residuals, at all possible leads and lags, are not significantly different from zero. The causality pattern is indicated by significant cross correlations. An appealing feature of the two-stage approach is that the asymptotic distribution of the test statistic does not depend on the normality assumption. This property is quite relevant for the current study since Eurodollar interest rates do not satisfy the normality assumption.

Cross correlation computed from the standardized residuals of the AR-GARCH models of table 2 are given in table 5. The "lag" refers to the number of days that the spot data lag behind the futures data. A lead is given by a negative lag. Significance of a statistic with a positive lag implies the spot data cause the futures data. It is noted that data on Eurodollar spot and futures interest rates are not synchronized. The spot market in London closes before the opening of the futures market in the International Monetary Market. Thus, a lag-zero cross correlation, which measures the co-movement in the same calendar day, should be interpreted as evidence that the spot interest rate causes the futures rate. The column labeled "Levels" gives the cross correlation 
statistics based on standardized residuals themselves. These statistics are for testing causality in the mean. Cross correlation statistics under the "squares" column are based on the squares of standardized residuals and are used to test for causality in the variance.

Compared with the Granger causality test results reported in table 4, cross correlation statistics reveal a more complex and dynamic causation pattern. For instance, the feedback effects in the means involve a higher-order lag structure. Further, there is evidence that the causality in variance goes from the futures data series to the spot price series and vice versa. These results show that a proper account of conditional heteroskedasticity can have significant implications for the study of price and volatility spillovers. The information flows between the spot and futures markets affect not only price movements, but also volatility movements, in these two markets.

Cheung and $\mathrm{Ng}$ (1996) illustrate that the cross-correlation statistics offer some useful information on the interaction between time series. Such information can be exploited to build a better model to describe the time-series dynamics of the data. We adopted the following approach to extract information from cross-correlation statistics computed from the Eurodollar spot and futures interest rates. Using the information in table 5, we estimate an augmented AR-GARCH model for each interest rate series by incorporating the relevant lagged (and squared) data of the other series to its original AR-GARCH model reported in table 2. Again, the error correction term is included to allow for the possible effect of deviations from the long-run relationship.

Based on the estimation and diagnostic test results, we modify the augmented models until they pass $Q$ and $Q^{2}$ tests. For the Eurodollar spot interest rate data, the resulting model is

$$
\Delta S_{t}=a_{0}+\sum_{i=1}^{p 1} a_{i} \Delta S_{t-i}+\sum_{i=1}^{p 2} b_{i} \Delta F_{t-i}+d E_{t-1}+\varepsilon_{s, t},
$$

where $\varepsilon_{s, t \mid t-1} \sim N\left(0, h_{s, t}\right)$,

$$
h_{s, t}=\beta_{0}+\sum_{i=1}^{p 3} \beta_{i} \varepsilon_{s, t-i}^{2}+\sum_{i=1}^{p 4} \gamma_{i} h_{s, t-i}+\sum_{i=1}^{p 5} \delta_{i} \Delta F_{t-i}^{2} .
$$

The augmented model for the futures data is 
TABLE 6. Augmented AR-GARCH Models for the Eurodollar Spot and Futures Interest Rates Data

\begin{tabular}{lrrrr}
\hline & \multicolumn{2}{c}{ Spot } & \multicolumn{2}{c}{ Futures } \\
\hline$a_{1}$ & -.2515 & $(-14.37)$ & -.0991 & $(-6.37)$ \\
$a_{2}$ & -.1120 & $(-6.41)$ & -.0485 & $(-2.54)$ \\
$b_{0}$ & & & .4113 & $(16.58)$ \\
$b_{1}$ & .4155 & $(26.18)$ & .1209 & $(5.06)$ \\
$b_{2}$ & .1278 & $(8.21)$ & .0666 & $(3.08)$ \\
$b_{3}$ & .0538 & $(3.36)$ & .0141 & $(.77)$ \\
$d$ & -.0349 & $(-7.40)$ & .0146 & $(2.57)$ \\
$\beta_{0}$ & .0054 & $(9.99)$ & .0014 & $(8.99)$ \\
$\beta_{1}$ & .0567 & $(12.96)$ & .0011 & $(12.23)$ \\
$\gamma_{1}$ & .9071 & $(19.97)$ & .0062 & $(13.88)$ \\
$\delta_{0}$ & & & .2440 & $(19.43)$ \\
$\delta_{1}$ & .1354 & $(12.58)$ & -.2318 & $(-18.01)$ \\
$\delta_{2}$ & -.1150 & $(-12.70)$ & & \\
Log-likelihood & 5207.31 & & \\
$Q(5)$ & & 7.75 & & 16287.88 \\
$Q(10)$ & & 12.30 & & 1.78 \\
$Q^{2}(5)$ & & 5.80 & & 2.94 \\
$Q^{2}(10)$ & & 8.66 & &
\end{tabular}

Note: The table presents estimates for the augmented AR-GARCH models given by equations 7, 8, 9, and 10. $\beta_{0}$ is scaled by a factor of $100 . Q(k)$ and $Q^{2}(k)$ are the Ljung-Box statistics calculated from the first $k$ autocorrelation coefficients of the standardized residuals and their squares. $t$-values are given in parentheses.

$$
\Delta F_{t}=a_{0}+\sum_{i=1}^{p 1} a_{i} \Delta F_{t-i}+\sum_{i=0}^{p 2} b_{i} \Delta S_{t-i}+d E_{t-1}+\varepsilon_{f, t}
$$

where $\varepsilon_{f, t \mid t-1} \sim N\left(0, h_{f, t}\right)$,

$$
h_{f, t}=\beta_{0}+\sum_{i=1}^{p 3} \beta_{i} \varepsilon_{f, t-i}^{2}+\sum_{i=1}^{p 4} \gamma_{i} h_{f, t-i}+\sum_{i=1}^{p 5} \delta_{i} \Delta S_{t-i}^{2}
$$

The maximum likelihood estimates and the cross-correlation statistics computed from the standardized residuals of the augmented models are presented in tables 6 and 7, respectively. The added variables are significant, while the $Q$-statistics are not significant. Their incremental explanatory power is manifested by changes in the maximum likelihood values. The log-likelihood increases from 4,772 to 5,207 for the spot series and from 3,999 to 4,288 for the futures data (tables 2 and 6). The 
TABLE 7. Cross-Correlation Analysis for the Levels and Squares of Standardized Results from the Augmented AR-GARCH Models of Table 6

\begin{tabular}{rrrrrr}
\hline Lag k & Levels & Squares & Lag k & Levels & Squares \\
\hline-10 & .4576 & -.7081 & 1 & 1.2581 & -.6312 \\
-9 & -.4024 & .1742 & 2 & 1.4348 & -.4807 \\
-8 & -1.7928 & -.2588 & 3 & 1.1826 & .0512 \\
-7 & .9947 & -1.2815 & 4 & -.0292 & -.5135 \\
-6 & 1.2909 & -.4800 & 5 & 1.0541 & .5574 \\
-5 & 1.8569 & -.4425 & 6 & -.3846 & .5717 \\
-4 & .2420 & -.9080 & 7 & .8570 & -1.1978 \\
-3 & -.0337 & -.7720 & 8 & .0776 & -.8081 \\
-2 & .3602 & .0039 & 9 & 1.1758 & -.1216 \\
-1 & -.4524 & .4296 & 10 & .7525 & 1.6828 \\
0 & .6571 & .3906 & & & \\
& & & & & \\
\hline
\end{tabular}

Note: Sample cross-correlation statistics are calculated from standardized residuals and their squares obtained from models reported in table 6. "Lag" refers to the number of days the spot data lag the futures data. A lead is given by a negative lag parameter. No coefficient estimate is significant at the $5 \%$ level.

results indicate that there are feedback effects in both the mean and the variance. Furthermore, the causation patterns revealed in the models in table 6 are more complicated than those in table 5. Nonetheless, data on futures still appear to have a more prominent impact on both the mean and the volatility of spot rates.

Comparing the results in table 5 and table 7 , we observe that the interaction between the error terms of these two augmented AR-GARCH models, as indicated by the cross correlation statistics, is much weaker than that in the original AR-GARCH models. All the cross-correlation statistics in table 7 are insignificant. This result suggests that our augmented AR-GARCH model provides a good description of both the Eurodollar spot and futures deposit rate dynamics and the interaction between the two interest rate series.

The construction of the univariate augmented AR-GARCH models can be seen as the first step of building a bivariate model for the Eurodollar spot and futures interest rates. For instance, the lag structure uncovered in the augmented models helps determine the lag structure of the bivariate GARCH model. There is a strong justification for pursuing a bivariate model even though one expects the causality pattern derived from the bivariate model will be similar to the pattern reported in table 6 . Theoretically, a correctly specified bivariate model 
will give a more precise description of the interaction between Eurodollar spot and futures rates. However, there appears to be a lack of consensus on the (asymptotic) behavior of the parameter estimates of a multivariate GARCH model (Engle and Kroner [1995, p. 141]). As the distributional aspect of multivariate models is beyond the scope of the current paper, we leave the estimation and the subsequent statistical analysis of a multivariate model as a future research topic.

\section{Concluding Remarks}

This article examines the relationship between three-month Eurodollar spot and futures interest rates during the period January 1983 to July 1997. The Cheung and Ng (1996) procedure, which is asymptotically robust to distributional assumptions, is employed to test for causality in both the mean and the variance. The observed causation pattern, which is controlled for both conditional mean and variance variations, indicates that there are feedback effects between the spot and futures markets. Movements in spot interest rates and their volatility tend to induce fluctuations in futures data, but the futures rate tends to have a stronger impact on the spot rate.

The causation patterns are in accordance with the price discovery function of a futures market in that the Eurodollar futures interest rate provides some incremental explanatory power for Eurodollar spot interest rate movements. Since both futures and spot interest rates are associated with the same financial instrument, there is a strong theoretical reason to expect these two rates to be closely linked. In fact, we found that the two interest rate series are cointegrated.

As evidenced in tables 4 and 6, incremental information does not come only from lagged changes in futures rates. It also derives from the lagged spread between the spot and futures rates. That is, not just the futures rate itself, but also its deviation from the spot rate, contains useful information about variations in the Eurodollar spot interest rate. Furthermore, the flow of information from the futures to the spot market is indicated by the causality in variance results.

The study of the dynamics of Eurodollar spot and futures rates can benefit significantly from a proper description of interest rate volatility. By explicitly modeling conditional variance dynamics, we can easily investigate the possibility of volatility spillover and have a clearer understanding of the price interactions in the spot and futures markets. 
Our results show that information flows between the spot and futures markets can be reflected in both price and volatility spillovers. Thus, the analysis of the pricing function should not be limited to the study of the relationship between the returns on spot and futures markets.

In addition to the information flow pattern, the causality test yields valuable information on data dynamics. Such information can be exploited to build a better model to describe conditional mean and conditional variance behavior. Our estimation results strongly suggest that the information extracted from the causality tests can lead to dramatic improvement in the ability to explain interest rate dynamics. For practitioners, a better model of interest rate movements can lead to a better assessment of the costs of funding and capital budgeting. Therefore, the conditional variance dynamics prescribed in the augmented AR-GARCH models may prove useful in risk management. Thus, a potential future research topic is to evaluate whether a better understanding of the mean and variance causality pattern helps improve interest rate risk management.

\section{References}

Baillie, R. T. and Bollerslev, T. 1991. Intra-day and inter-market volatility in foreign exchange markets. Review of Economics Studies 58: 565-585.

Bessler, D. A. and Covey, T. 1991. Cointegration: some results on U.S. cattle prices. Journal of Futures Markets 11: 461-471.

Chan, K. 1992. A further analysis of the lead-lag relationship between the cash market and stock index futures market. Review of Financial Studies 5: 123152.

Chan, K.; Chan, K. C.; and Karolyi, A. 1991. Intra day volatility in the stock index and stock index futures markets. Review of Financial Studies 4: 657684.

Chan, K. C.; Karolyi, A.; Longstaff, F. A.; and Saunders, A. 1992. A comparison of alternative models of the short-term interest rates. Journal of Finance 47: 1209-1227.

Cheung, Y. -W. and Lai, K. S. 1993. Finite-sample sizes of Johansen's likelihood ratio tests for cointegration. Oxford Bulletin of Economics and Statistics 55: 313-328.

Cheung, Y. -W. and Lai, K. S. 1995. Lag order and critical values of the augmented Dickey-Fuller test. Journal of Business and Economics Statistics 13: 277-280.

Cheung, Y. -W. and Ng, L. K. 1996. A causality-in-variance test and its application to financial market prices. Journal of Econometrics 72: 33-48. 
Engle, R. F. 1982. Autoregressive conditional heteroskedasticity with estimates of the variance of United Kingdom inflation. Econometrica 50: 987-1007.

Engle, R. F.; Ito, T.; and Lin, K. L. 1990. Meteor showers or heat waves? Heteroskedastic intra-daily volatility in the foreign exchange market. Econometrica 58: 525-542.

Engle, R. F.; Lilien, D. M.; and Robins, R. P. 1987. Estimating time varying risk premia in the term structure: The ARCH-M model. Econometrica 55: 391-407.

Engle, R. F. and Kroner, K. F. 1995. Multivariate simultaneous generalized ARCH. Econometric Theory 11: 122-150.

Fama, E. and French, K. R. 1987. Commodity futures prices: some evidence on forecast power, premiums, and the theory of storage. Journal of Business, $60,55-73$.

Fung, H. G. and Leung, W. K. 1993. The pricing relationship of Eurodollar futures and Eurodollar deposit rates. Journal of Futures Market 13: 115125.

Garbade, K. D., and Silber, W. L. 1983. Price movements and price discovery in the futures and cash markets. Review of Economics and Statistics 65: 289-297.

Herbst, A. F.; McCormack, J.; and West, E. 1987. Investigation of a lead-lag relationship between spot stock indices and their futures contracts. Journal of Futures Markets 7: 373-381.

Hamao, Y.; Masulis, R. W.; and Ng, V. 1990. Correlations in price changes and volatility across international stock markets. Review of Financial Studies 3: 281-307.

Hein, S. and MacDonald, S. S. 1993. An empirical evaluation of treasury-bill futures market efficiency: evidence from forecast efficiency tests. Journal of Futures Markets 17: 373-381.

Johansen, S. 1991. Estimation and hypothesis testing of cointegration vectors in Gaussian vector autoregressive model. Econometrica 59: 571-581.

Khoury, N. T. and Yourougou, P. 1991. The information content of the basis: evidence from Canadian Barley, Oats, and Canola futures markets. Journal of Futures Markets 11: 69-80.

Koutmos, G. and Theodossiou, P. 1994. Time-series properties and predictability of Greek exchange rates. Managerial and Decision Sciences 15: 159-167.

Krehbiel T. and Adkins, L. C. 1994. Interest rate futures: evidence on forecast power, expected premiums and the unbiased expectation hypothesis. Journal of Futures Markets 14: 531-543.

Kwiatkowski, D.; Phillips, P. C. B; Schmidt, P. J.; and Shin, Y. 1992. Testing the null hypothesis of stationarity against the alternative of a unit root: How sure are we that economic time series have a unit root? Journal of Econometrics 54: 159-78

Melton, C. R. and Pukula, T. V. 1984. Financial Futures: Practical 
Applications for Financial Institutions. Virginia: Reston Publishing Co. MacDonald S. and Hein, S. E. 1989. Futures and forward rates as predictors of near-term treasury bill rates. Journal of Futures Markets 9: 249-262.

Najand, M.; Rahman, H.; and Yung, K. 1992. Inter-currency transmission of volatility in foreign exchange futures. Journal of Futures Markets 12: 609620.

Phillips, P. C. B. 1991. Optimal inferences in cointegrated systems. Econometrica 55: 277-301

Ross, S. A. 1989. Information and volatility: the no-arbitrage Martingale approach to timing and resolution irrelevancy. Journal of Finance 44: 1-17.

Stoll H. R. and Whaley, R. E. 1990. The dynamics of stock index and stock index futures returns. Journal of Financial and Quantitative Analysis 25: 441-468.

Susmel, R., and Engle, R. F. 1994. Hourly volatility spillover between national equity markets. Journal of International Money and Finance 13: 3-25.

Theodossiou, P. 1994. The stochastic properties of major Canadian exchange rates. Financial Review 29: 193-221.

Theodossiou, P., and Lee, U. 1993. Mean and volatility spillover across major national stock markets: Further empirical evidence. Journal of Financial Research 16: 337-350.

Tse, Y. and Booth, G. G. 1997. Information shares in international oil futures markets. International Review of Economics and Finance 6: 49-56. 